\title{
STATE OF VIRAL HEPATITIS CARE IN 16 COUNTRIES OF CENTRAL AND EASTERN EUROPEAN REGION
}

\author{
Nikoloz Chkhartishvili', Tiberiu Holban², Jasmina Simonović Babić ${ }^{3}$, Ivailo Alexiev ${ }^{4}$, Mojca Matičič ${ }^{5}$, Justyna \\ Kowalska ${ }^{6}$, Andrzej Horban ${ }^{6}$; ECEE Network Group \\ ${ }^{1}$ Infectious Diseases, AIDS and Clinical Immunology Research Centre, Tbilisi, Georgia \\ ${ }^{2}$ Nicolae Testemilanu State University of Medicine and Pharmacy, Chisinau, Republic of Moldova \\ ${ }^{3}$ Faculty of Medicine Belgrade University, Clinic of Infectious Diseases, Belgrade, Serbia \\ ${ }^{4}$ National Centre of Infectious and Parasitic Diseases, Sofia, Bulgaria \\ EUniversity Medical Centre Ljubljana, Ljubljana, Slovenia \\ ${ }^{6}$ Hospital for Infectious Diseases, Medical University of Warsaw, Warsaw, Poland
}

\section{SUMMARY}

Objectives: Survey was conducted to assess state of viral hepatitis care in Central and Eastern Europe (CEE).

Methods: Representatives of 16 CEE countries completed on-line survey in April-May 2017 that collected information on basic epidemiology and availability of key services for HCV and HBV infections. Sources of information provided ranged from national surveillance data to expert opinion.

Results: The burden of viral hepatitis varied between countries, ranging from 6,500 to 2 million for HCV and from 10,000 to 3 million for HBV. Access to routine HCV RNA testing and genotyping was reported by 11 and 9 countries, respectively. HCV resistance testing was available in 7 countries. Direct acting antivirals (DAAs) were available in 13 countries, most frequently Sofosbuvir and Ledipasvir/Sofosbuvir (12 countries apiece) and Ombitasvir/Paritaprevir/Dasabuvir (9 countries). HBV DNA testing and HBV genotyping were routinely available in 10 and 7 countries, respectively. Eleven countries reported available treatment with Tenofovir.

Conclusions: There are gaps in viral hepatitis care in CEE. Despite the availability of registered modern drugs for HCV and HBV, the access to treatment is limited. Ensuring quality health care is essential to reduce the epidemic and achieve the WHO's goal of eliminating viral hepatitis as a major public health challenge.

Key words: viral hepatitis, Central and Eastern Europe, HCV, HBV

Address for correspondence: N. Chkhartishvili, AIDS and Clinical Immunology Research Centre, 6 Al. Kazbegi Avenue, Tbilisi 0160 , Georgia. E-mail: nc@aidscenter.ge

https://doi.org/10.21101/cejph.a5486

\section{INTRODUCTION}

Viral hepatitis due to hepatitis B virus (HBV) and hepatitis $\mathrm{C}$ virus (HCV) represent major health challenge globally. Both viruses can cause chronic hepatitis that may lead to cirrhosis and hepatocellular carcinoma $(1,2)$. The World Health Organization (WHO) estimates that there are more than 300 million people living with chronic HBV and HCV infection globally including 29 million people living in the WHO European Region resulting in 171,000 deaths annually $(3,4)$.

Currently available prevention and treatment modalities make the goal of viral hepatitis elimination technically feasible (5). This includes highly effective vaccine against $\mathrm{HBV}$, antiviral drugs to control HBV and new generation direct acting antivirals (DAAs) curing $>95 \%$ of $\mathrm{HCV}$ infections $(1,6)$. However, there are important challenges to overcome, including gaps in prevention, diagnosis and treatment (3).

Latest global hepatitis report shows that only $9 \%$ of people living with $\mathrm{HBV}$ and $20 \%$ of people living with $\mathrm{HCV}$ are aware of their status (3). Only $8 \%$ of those diagnosed with HBV and $\mathrm{HCV}$ infections received antiviral therapy (3). Access to effective treatment is substantially hampered by high costs of both HBV and HCV drugs (7), which are often inaccessible to all patients through health systems. While prevention can reduce the rate of new infections, the number of chronically infected persons would remain high for years, therefore, ensuring testing, virological monitoring and unrestricted access to treatment is crucial for achieving elimination goal.

We conducted survey to assess state of viral hepatitis care within the Euroguidelines in Central and Eastern Europe (ECEE) Network Group, which was formed in 2016 to promote dissemination of European standards of care in HIV and viral hepatitis in Central and Eastern Europe (CEE) (8).

\section{MATERIALS AND METHODS}

On-line survey was constructed to elicit information related to $\mathrm{HCV}$ and HBV care in CEE region. The survey asked respondent to answer 17 question, including 2 general questions about the country of residence and occupation, 8 questions about $\mathrm{HCV}$ epidemiology and availability of $\mathrm{HCV}$ diagnostic and treatment 
services, and 7 questions about HBV epidemiology and availability of HBV diagnostic and treatment services. Questions were primarily pre-defined multiple choice questions with an option to provide free text response in "Other" section. Questions were reviewed by field experts for content validity. Survey content is provided in Table1. Informed consent was not sought as survey did not collect any identifiable private information about the respondent or any other individual.
Data collection took place in April-May 2017. Overall 17 respondents participated from 16 CEE countries (Albania, Armenia, Bosnia and Herzegovina, Bulgaria, Croatia, Estonia, Georgia, Greece, Hungary, Poland, Republic of Moldova, Romania, Serbia, Slovenia, Turkey, Ukraine). Majority of respondents (76\%) were HIV or other specialty clinicians, there were two epidemiologists, a head of national reference laboratory and a manager of national programme. Respondents were asked to provide the source of

Table 1. Survey content

\begin{tabular}{|c|c|c|}
\hline No & Question & Answers \\
\hline 1 & What is your country? & Text \\
\hline \multirow[t]{4}{*}{2} & \multirow[t]{4}{*}{ What is your current occupation? } & a) HIV clinician \\
\hline & & b) Other specialty clinician \\
\hline & & c) Epidemiologist \\
\hline & & d) Other (to be specified) \\
\hline 3 & What is the number of HCV infected persons in your country? & Number \\
\hline \multirow[t]{4}{*}{4} & \multirow[t]{4}{*}{ Which group is dominating among HCV positive persons? } & a) People who inject drugs \\
\hline & & b) Medical procedure in anamnesis \\
\hline & & c) Unknown \\
\hline & & d) Other (to be specified) \\
\hline \multirow[t]{5}{*}{5} & \multirow{5}{*}{$\begin{array}{l}\text { Which groups are routinely tested in public healthcare system } \\
\text { for HCV infection (anti-HCV antibodies)?* }\end{array}$} & a) Blood and organ donors \\
\hline & & b) Populations at risk e.g. PWID, MSM, sex workers \\
\hline & & c) Medical procedure in anamnesis \\
\hline & & d) Pregnant women \\
\hline & & e) Other (to be specified) \\
\hline \multirow[t]{3}{*}{6} & \multirow[t]{3}{*}{ Do you have access to routine HCV RNA testing? } & a) Yes \\
\hline & & b) Periodically \\
\hline & & c) No \\
\hline \multirow[t]{3}{*}{7} & \multirow[t]{3}{*}{ Do you have access to routine HCV genotyping? } & a) Yes \\
\hline & & b) Periodically \\
\hline & & c) No \\
\hline \multirow[t]{3}{*}{8} & \multirow[t]{3}{*}{ Do you have access to routine HCV resistance testing? } & a) Yes \\
\hline & & b) Periodically \\
\hline & & c) No \\
\hline \multirow[t]{4}{*}{9} & \multirow{4}{*}{$\begin{array}{l}\text { Describe antiviral treatment available for } \mathrm{HCV} \text { infection in } \\
\text { public health care (free of charge): }\end{array}$} & a) DAA original products \\
\hline & & b) DAA generic products \\
\hline & & c) Interferon + RBV only \\
\hline & & d) No treatment is available \\
\hline \multirow[t]{8}{*}{10} & \multirow{8}{*}{$\begin{array}{l}\text { Do you have DAA drugs available in your country infection in } \\
\text { public health care (free of charge)?* }\end{array}$} & a) Simeprevir (SMV) \\
\hline & & b) Boceprevir (BCV) \\
\hline & & c) Sofosbuvir (SOF) \\
\hline & & d) Ledipasvir/Sofosbuvir (LED/SOF) \\
\hline & & e) Daclatasvir (DCV) \\
\hline & & f) Elbasvir/Grazoprevir (EBR/GZR) \\
\hline & & g) Ombitasvir/Paritaprevir/Ritonavir + Dasabuvir (OMB/PTV/r + DAS) \\
\hline & & h) Other \\
\hline 11 & What is the number of HBV infected persons in your country? & Number \\
\hline
\end{tabular}

Continued on the next page 
Continued from the previous page

\begin{tabular}{|c|c|c|}
\hline No & Question & Answers \\
\hline \multirow[t]{4}{*}{12} & \multirow[t]{4}{*}{ Which group is dominating among HBV positive persons? } & a) Injecting-drug users \\
\hline & & b) Persons with medical procedure in anamnesis \\
\hline & & c) Unknown \\
\hline & & d) Other (to be specified) \\
\hline \multirow[t]{5}{*}{13} & \multirow{5}{*}{ 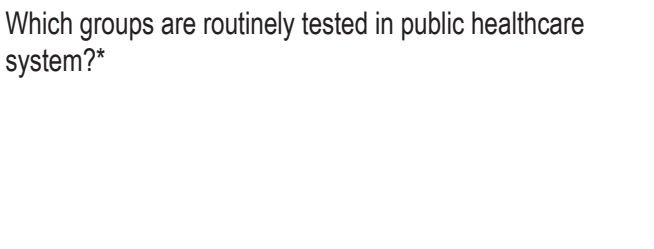 } & a) Blood and organ donors \\
\hline & & b) Populations at risk e.g. IDU, MSM, sex workers \\
\hline & & c) Medical procedure in anamnesis \\
\hline & & d) Pregnant women \\
\hline & & e) Other (to be specified) \\
\hline \multirow[t]{3}{*}{14} & \multirow[t]{3}{*}{ Do you have access to routine HBV DNA testing? } & a) Yes \\
\hline & & b) Periodically \\
\hline & & c) No \\
\hline \multirow[t]{3}{*}{15} & \multirow[t]{3}{*}{ Do you have access to routine HBV genotyping? } & a) Yes \\
\hline & & b) Periodically \\
\hline & & c) No \\
\hline \multirow[t]{5}{*}{16} & \multirow{5}{*}{$\begin{array}{l}\text { Which antiviral treatment is available for HBV infection } \\
\text { in public health care?*}\end{array}$} & a) Tenofovir \\
\hline & & b) Entecavir \\
\hline & & c) Lamivudine \\
\hline & & d) Interferon \\
\hline & & e) Other (to be specified) \\
\hline \multirow[t]{4}{*}{17} & \multirow{4}{*}{$\begin{array}{l}\text { Describe availability in public health care for end stage liver } \\
\text { disease treatment* }\end{array}$} & a) Liver transplantation for HIV negative \\
\hline & & b) Liver transplantation for HIV positive \\
\hline & & c) None \\
\hline & & d) Other (to be specified) \\
\hline
\end{tabular}

${ }^{*}$ Multiple answers possible

information, which ranged from national survey and surveillance data to expert opinion.

\section{RESULTS}

Among 17 respondents 13 (76.5\%) were either HIV or other specialty clinicians, among remaining four persons - two were epidemiologists, one head of national reference laboratory and one programme manager.

The burden of viral hepatitis varied between countries with estimated 10,000 to 3 million individuals with HBV and from 6,500 to 2 million $\mathrm{HCV}$ infections. Based on provided data, at least 5 million people live with $\mathrm{HBV}$ and 3.7 million with $\mathrm{HCV}$ infection in CEE region. Injection drug use was the major risk factor for $\mathrm{HCV}$ infection, reported by $9(52.9 \%)$ countries, while HBV was most frequently associated with history of medical procedures $-8(50 \%)$ countries.

Blood and organ donors were screened for both infections in all countries. Screening policies for other populations varied by country. Pregnant women were screened for HBV in 12 (75.0\%) and for HCV in $9(56.3 \%)$ countries. Populations at risk were screened for HBV in $10(62.5 \%)$ and for HCV in $12(75.0 \%)$ countries. Only $4(25.0 \%)$ countries had policy of screening people with history of medical procedures both for HBV and HCV infections (Fig. 1).

Not all countries ensure routine access to molecular diagnostic methods (Fig. 2). HBV DNA testing and HBV genotyping was routinely available in $10(62.5 \%)$ and $7(43.8 \%)$ countries, respectively. HCV RNA testing was routinely accessible in 11 $(68.8 \%)$ countries, with $9(56.3 \%)$ countries ensuring access to HCV genotyping.

Eleven $(68.8 \%)$ countries reported availability of treatment with Tenofovir for HBV infection (Fig. 3). DAAs for HCV in-

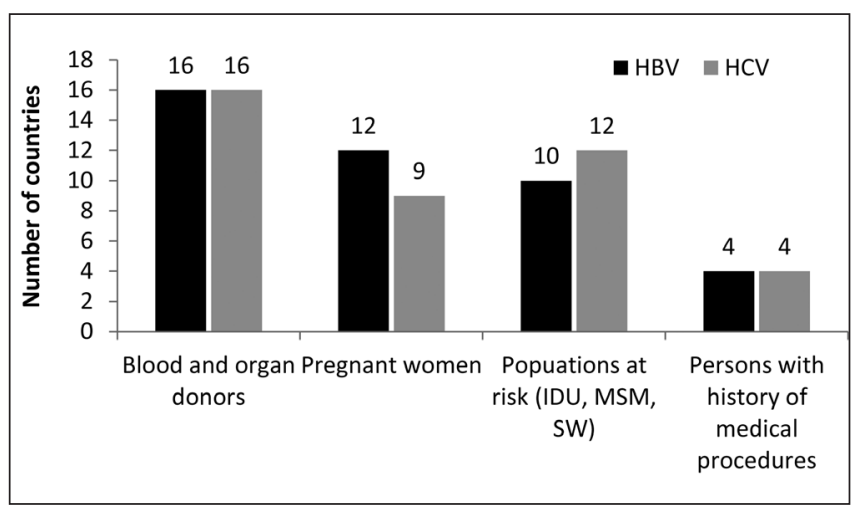

Fig. 1. Populations routinely screened for HBV and HCV. 


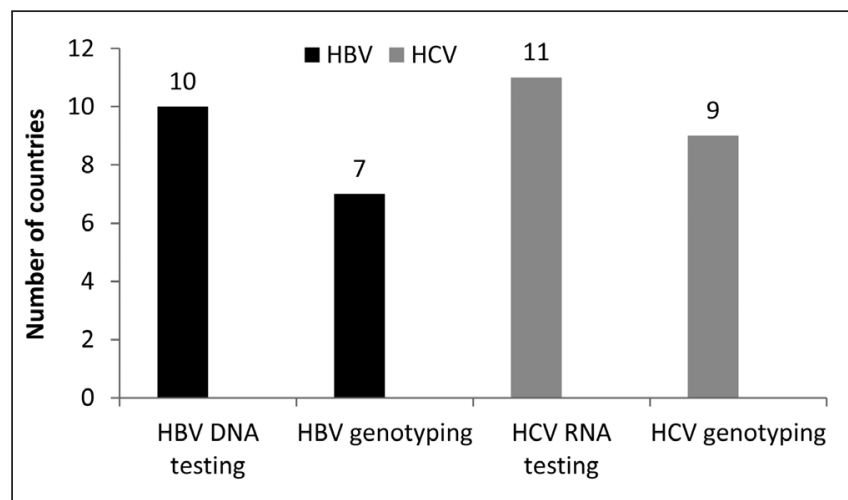

Fig. 2. Routine availability of molecular diagnostics.

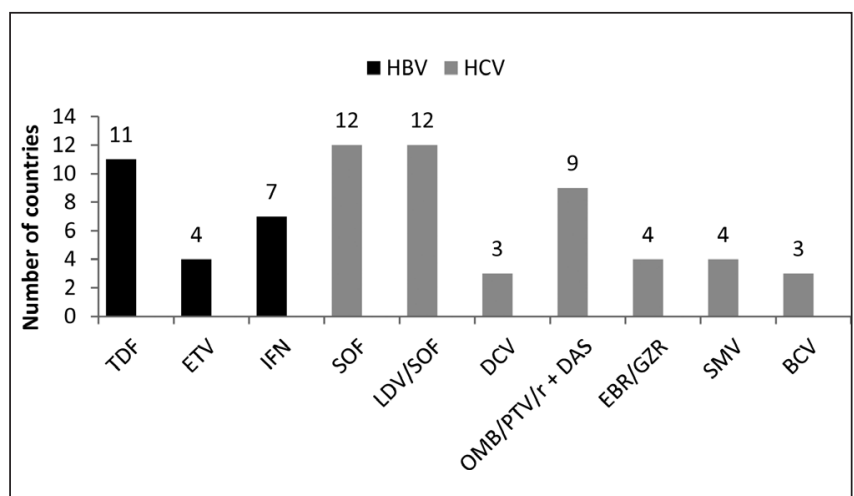

Fig. 3. Routine availability of $\mathrm{HBV}$ and $\mathrm{HCV}$ medicines.

TDF - Tenofovir; ETV - Entecavir; IFN - Interferon; SOF - Sofosbuvir; LDV/SOF - Ledipasvir/Sofosbuvir; DCV - Daclatasvir; OMB/PTV/r + DAS - Ombitasvir/Paritaprevir/Ritonavir + Dasabuvir; EBR/GZR - Elbasvir/Grazoprevir; SMV - Simeprevir; BCV - Boceprevir

fection were available in $13(81.4 \%)$ countries. Most commonly available DAAs were Sofosbuvir (12 countries, 75.0\%), Ledipasvir/Sofosbuvir (12 countries, $75.0 \%$ ) and Ombitasvir/Paritaprevir/ Ritonavir + Dasabuvir ( 9 countries, 56.3\%).

\section{DISCUSSION}

This was the first survey to evaluate access to hepatitis care in CEE region primarily from the clinicians' perspective. Our survey indicates that there are gaps in viral hepatitis care that need to be addressed in order to improve surveillance and treatment and thus make the elimination goal feasible. Action plan for the health sector response to viral hepatitis in the WHO European Region, unanimously approved by all member states in 2016, provides roadmap towards hepatitis elimination with measurable targets to be achieved across the continuum of hepatitis services.

It is agreed that successful engagement in the continuum depends on testing, which is the gateway to treatment and care. Survey showed existing testing policies and practices may result in missed opportunities to diagnose both HBV and HCV. For example, while eight countries identified persons with history of medical procedures as the dominant in $\mathrm{HBV}$, only 4 countries reported availability of routine testing for this population. People who inject drugs and pregnant women are also missed in screening programmes in some CEE countries. It should be noted that gaps in hepatitis testing are also visible in more affluent parts of Europe and as a result only $13 \%$ of $\mathrm{HBV}$-infected persons and $30 \%$ of $\mathrm{HCV}$-infected individuals are diagnosed in the entire European region $(3,9)$.

The price is considered to be the key driver affecting access to diagnostic and treatment services in general, therefore, economic situation in CEE should be taken into account. Based on the World Bank classification, of 16 countries participating in this survey majority (11 countries) have lower- or middle-income economies. Five countries are classified as high income, yet their per capita gross national income (GNI) is significantly lower than average of the European Union (World Bank, GNI per capita, Atlas method*).

Current economic situation in surveyed countries may explain limited accessibility of molecular diagnostics for HBV and HCV. With regard to treatment, all countries reported availability of some treatment. For HBV, Tenofovir most commonly available drug, with Entecavir use reported by 4 countries (including 3 high income countries). It should be noted that in non-EU member CEE countries Tenofovir is available as generic product at significantly lower price as compared to originator, but at the same use of Tenofovir for HBV might be limited to HIV co-infected populations (10).

Uptake of HCV treatment is low in the entire WHO European region, with only $5 \%$ of those diagnosed receiving treatment (3). Coverage declines as we go from the West to the East as it was demonstrated in recent publications, including the EuroSIDA report that showed twice as lower uptake of DAA based treatment in CEE countries compared to Western and Northern Europe among HIV/HCV co-infected persons $(11,12)$. High price of new generation DAAs results in restricted prescriptions not only in middle-income countries, but also in high-income settings. Analysis of data from countries in the European Union and European Economic Area, and Switzerland identified that nearly half of these countries restricted reimbursement of DAA based treatment to more advanced stages of liver disease, and further $17 \%$ had restrictions related to active substance use (13).

High prices and restricted access resulted in emergence of so call "buyer's clubs" that implies importation of low cost generic DAAs from countries producing these drugs through voluntary licensing (14). Importation schemes had been documented in the European region and it has been suggested that these drugs are as effective as originator products (15).

Limitations should be acknowledged. Survey had narrow representation of key stakeholders and it was primarily limited to clinicians. Inclusion of policy makers and civil society representatives might have brought different perspective. Survey covered only testing and care aspects of viral hepatitis without addressing primary prevention, which remains essential component of comprehensive response measures. Reports indicate that there is need for improving HBV immunization in children and especially among key populations at risk along with improving access to harm reduction services $(3,16)$. Another limitation is that not all countries of CEE region participated in the survey and we might have missed important data. For example, the Czech Republic has made important progress in providing HCV treatment, reimbursing all currently available DAAs (17), and

*https://data.worldbank.org/indicator/NY.GNP.PCAP.CD 
providing $\mathrm{HBV}$ treatment to $14 \%$ of those eligible, which is well above the regional average (18).

It should be noted that response to viral hepatitis, especially to $\mathrm{HCV}$, has been scaling-up in CEE region and substantial progress has been made in many countries after conducting the survey. In most of the surveyed countries reimbursements for DAAs are available, however, minimum fibrosis stage based restrictions remain in many countries (19). Georgia has been leading in terms of HCV treatment uptake with up to 50,000 persons initiating DAA treatment (20). HCV treatment uptake has been increasing in other countries as well including Poland, Romania and Ukraine. However, overall progress in the region remains unsatisfactory (21). Less progress has been made in treating HBV, with an estimated $<1-5 \%$ of eligible patients receiving treatment, with the highest coverage reported in Turkey (14\%) and Slovenia (17\%) (18).

\section{CONCLUSIONS}

Our study provides important insights into the state of viral hepatitis care in CEE region and can serve as a benchmark for assessing the future progress. There is clear need for improving access to testing and treatment through stronger commitment and political leadership. Innovative approaches for financing response activities should be identified including through public-private partnerships and market oriented mechanisms. Lessons learned from HIV field should be explored in hepatitis field including voluntary pooled procurement, which has been shown to be effective in significantly reducing prices of HIV medicines (22). In summary, momentum for hepatitis elimination continues to grow and the opportunity needs to be seized to turn this momentum into effective action.

\section{Acknowledgement}

Members of ECEE Network Group:

Alexiev I (Bulgaria), Afonina L(Russia), Antonyak S (Ukraine), Balayan $\mathrm{T}$ (Armenia), Bednarska A** (Poland), Begovac J (Croatia), Bukovinowa P(Slovakia), Firląg-Burkacka E** (Poland), Bursa D (Poland), Bolokadze N (Georgia), Caplinskas S (Lithuania), Cholewińska-Szymańska G** (Poland), Chkhartishvili N (Georgia), de Witt S* (Begium), Dragovic G (Serbia), Gökengin D* (Turkey), Harxhi A (Albania), Higersberger J** (Poland), Holban T (Moldova), Horban A* (Poland), Jevtovic D (Serbia), Jilich D (Czech Republic), Karpov I (Belarusia), Konopnicky D (Belgium), Kowalska J* (Poland), Ladnaya N (Russia), Lakatos B (Hungary), Lundgren JD* (Denmark), Marczyńska M (Poland), Mardarescu M (Romania), Matłosz B (Poland), Molina JM (France)*, Mulabdic V (Bosnia-Herzegovina), Oprea C* (Romania), Otelea D (Romania), Paciorek $\mathrm{M}^{* *}$ (Poland), Panteleev A (Russia), Papadopoulos A (Greece), Pietraszkiewicz E (Poland), Podlasin B** (Poland), Podlekareva D (Denmark), Pozniak A* (United Kingdom), Pula J** (Poland), Sedlacek D (Czech Republic), Skrzat-Klapaczyńska A** (Poland), Simonović-Babić J (Serbia), Sluzhynska M (Ukraine), Streinu-Cercel A (Romania), Tomazic J (Slovenia), Rukhadze N (Georgia), Ruutel K (Estonia), Stańczak $\mathrm{J}^{* *}$ (Poland), Vassilenko A (Belarusia), Vasylyev M( Ukraine), Youle M* (United Kingdom), Yurin O (Russia), Zabłocka H (Poland)

Scientific Committee*, Organizing Committee**

\section{REFERENCES}

1. Trépo C, Chan HL, Lok A. Hepatitis B virus infection. Lancet. 2014 Dec 6;384(9959):2053-63.

2. Webster DP, Klenerman P, Dusheiko GM. Hepatitis C. Lancet. 2015;385(9973):1124-35.

3. Global hepatitis report, 2017. Geneva: World Health Organization; 2017.

4. Action plan for the health sector response to viral hepatitis in the WHO European Region. Copenhagen: World Health Organization; 2017.

5. Global health sector strategy on viral hepatitis, 2016-2021: towards ending viral hepatitis. Geneva: World Health Organization; 2016.

6. Rockstroh JK. HCV cure for everyone or which challenges remain? J Virus Erad. 2015 Apr 1;1(2):55-8.

7. Iyengar S, Tay-Teo K, Vogler S, Beyer P, Wiktor S, de Joncheere K, et al. Prices, costs, and affordability of new medicines for hepatitis C in 30 countries: an economic analysis. PLoS Med. 2016 May 31;13(5):e1002032. doi: 10.1371/journal.pmed.1002032.

8. Kowalska JD, Oprea C, de Witt S, Pozniak A, Gokengin D, Youle M, et al. Euroguidelines in Central and Eastern Europe (ECEE) conference and the Warsaw Declaration - a comprehensive meeting report. HIV Med. 2017 May;18(5):370-5.

9. European Centre for Disease Prevention and Control. Hepatitis B and C testing activities, needs, and priorities in the EU/EEA. Stockholm: ECDC; 2017.

10. Lemoine M, Nayagam S, Thursz M. Viral hepatitis in resource-limited countries and access to antiviral therapies: current and future challenges. Future Virol. 2013 Apr;8(4):371-80.

11. Maistat L, Kravchenko N, Reddy A. Hepatitis C in Eastern Europe and Central Asia: a survey of epidemiology, treatment access and civil society activity in eleven countries. Hepatol Med Policy. 2017 Jun 13;2:9. doi: 10.1186/s41124-017-0026-z.

12. Peters L, Laut K, Resnati C, Del Campo S, Leen C, Falconer K, et al; EuroSIDA Study Group. Uptake of hepatitis C virus treatment in HIV/ hepatitis $\mathrm{C}$ virus-coinfected patients across Europe in the era of directacting antivirals. AIDS. 2018 Sep 10;32(14):1995-2004.

13. Marshall AD, Cunningham EB, Nielsen S, Aghemo A, Alho H, Backmund $\mathrm{M}$, et al. Restrictions for reimbursement of interferon-free direct-acting antiviral drugs for HCV infection in Europe. Lancet Gastroenterol Hepatol. 2018;3(2):125-33.

14. Ghinea N, Lipworth W, Day R, Hill A, Dore GJ, Danta M. Importation of generic hepatitis $\mathrm{C}$ therapies: bridging the gap between price and access in high-income countries. Lancet. 2017 Mar 25;389(10075):1268-72.

15. Hill A, Khwairakpam G, Wang J, Golovin S, Dragunova J, Smith R, et al. High sustained virological response rates using imported generic direct acting antiviral treatment for hepatitis C. J Virus Erad. 2017 Oct 1;3(4):200-3.

16. Harm Reduction International. The Global State of Harm Reduction 2016. London: Harm Reduction International; 2016.

17. Marshall AD, Cunningham EB, Nielsen S, Aghemo A, Alho H, Backmund $\mathrm{M}$, et al. Restrictions for reimbursement of interferon-free direct-acting antiviral drugs for HCV infection in Europe. Lancet Gastroenterol Hepatol. 2018;3(2):125-33.

18. Polaris Observatory Collaborators. Global prevalence, treatment, and prevention of hepatitis B virus infection in 2016: a modelling study. Lancet Gastroenterol Hepatol. 2018;3(6):383-403.

19. Marshall AD, Pawlotsky J-M, Lazarus JV, Aghemo A, Dore GJ, Grebely J. The removal of DAA restrictions in Europe - One step closer to eliminating $\mathrm{HCV}$ as a major public health threat. J Hepatol. 2018 Nov;69(5):1188-96.

20. Tsertsvadze T, Gamkrelidze A, Chkhartishvili N, Abutidze A, Sharvadze L, Kerashvili V, et al. Progress towards achieving hepatitis C elimination in the countryof Georgia, April 2015-August 2018. J Hepatol. 2019;70(1 Suppl):e244-5.

21. Progress report on accees to hepatitis $C$ treatment: focus on overcoming barriers in low- and middle-income countries. Geneva: WHO; 2018.

22. Wafula F, Agweyu A, Macintyre K. Trends in procurement costs for HIV commodities: a 7-year retrospective analysis of global fund data across 125 countries. J Acquir Immune Defic Syndr. 2014 Apr 1;65(4):e134-9.

\section{Conflict of Interests}

